Journal of Social Sciences 4 (4): 288-298, 2008

ISSN 1549-3652

(C) 2008 Science Publications

\title{
Teaching Strategies and Class Practices of the Teachers who Teach Turkish as a Foreign Language (A Qualitative Research)
}

\author{
Ali Gocer \\ Department of Turkish Language Teaching, \\ Faculty of Education, Nigde University, Nigde, Turkey
}

\begin{abstract}
Problem statement: In the globalizing world, second language/foreign language has gained a great importance. The importance of the foreign language teaching has increased in our time in which knowing a foreign language has deviated from being a specialty and become a feature that everyone must have. For that purpose, teachers must know the characteristics of the learners very well and must enrich the learning environment with different techniques and materials in accordance with the environment facilities. Approach: In this study, it has been aimed to determine the language teaching strategies and class practices of the teachers who taught students of foreign origin in Turkey Turkish as a foreign language. To that end, interview and observation forms have been prepared. The content analysis of the data obtained with interview and observation forms has been conducted in the scope of qualitative research approach. Results: Teachers are not capable of giving an adequate language education due to such reasons as they did not receive a special education with the purpose of teaching Turkish as a foreign language and they preferred traditional methods instead of modern strategy and methods. Conclusions/Recommendations: In order to conduct language education in Turkey in accordance with the international norms, importance must be attached to the training of qualified language teachers, the significance of teaching Turkish as a foreign language must be discussed in academic environments and researches must be carried out.
\end{abstract}

Key words: Turkish teaching as a foreign language, teaching strategies, methods and techniques

\section{INTRODUCTION}

In order for the language teaching to be continued in accordance with the objectives, variables such as the social and physical dimensions of the environments, the quality of the utilized materials, the pedagogical background of the teacher, strategies, methods, etc. implemented by the teacher hold great importance. The most important of these variables is the quality of the teacher. Designing of the environment with a pedagogical point of view and the selection of the appropriate materials, strategies, methods and techniques are performed by the teacher. The progress of the learning and teaching process in accordance with the objectives is dependent on the experience of the teacher. The quality of the teacher is somehow reflected by the strategy and method that he implements and by his technical knowledge.

The relationship between these concepts which shape the process and directly affect the accomplishment of the goals was firstly mentioned by Edward Anthony. According to Anthony, approach is the level in which the assumptions about the language and language teaching are defined. There can be many methods in an approach. Method is the level in which the theory is implemented and the choices related to the skills and content to be taught and the teaching order of the content is made. Technique is the level for the various practices actually conducted in a classroom ${ }^{[1]}$. On the interrelated concept classification of Anthony, Tosun says ${ }^{[16]}$ : Approach is a number of assumptions about the nature of the language, learning and teaching. Method is the general plan of systematic language presentation based on a selected approach. Technique is consistent with the method and accordingly coherent to the approach and it is a special activity that is performed in the classroom. Richards and Rodgers ${ }^{[13]}$ base the three level concept arrangement of Anthony upon the implementation of a method by the techniques hierarchically and in the order of arrangement and the coherence of this method in accordance with an approach.

There are some basic principles which can shed a light upon the determination of strategy, method and technique to be followed in the language teaching studies. Demirel arranges these principles in the following order: developing the four basic skills, teaching from the simple to the complex, using the 
audio-visual tools, presenting a single structure at a time, enabling students to participate in the lesson more actively, taking into account of individual differences, etc. ${ }^{[7]}$. In accordance with these principles, foreign language teaching is actualized in the framework of structural, functional and interactive language theories ${ }^{[13]}$. The aforementioned principles and language theories require the implementation of cognitive, communicational, social, social-emotional, auditory-lingual, auditory-visual, functional-conceptual, natural approach and some techniques coherent to these approaches ${ }^{[4,6,7,11]}$.

In an educational system, the roles of the learners are closely related with the position and function of the teacher. The roles of the teacher are connected with the assumptions related to the language learning in approach level. Some methods provide teacher with knowledge and managing source, some methods limit the role of the teacher to being a counselor, catalyst and guider and some methods focus on the educational content by limiting the initiative of the teacher ${ }^{[13]}$. Apart from acting in accordance with structural, functional, interactive language theories, teachers can also offer students the opportunity to gain and learn basic language skills with the contribution of components such as students' eagerness, environment facilities, support of the school administration, etc. In this scope, learning must be considered not as a knowledge providing tool, but a way to become a more competent learner in the conducted studies ${ }^{[8]}$. In this respect, it is important for teachers to enable the learning and teaching process to become constantly dynamic and to diversify the activities by observing the feedback from the students and the general efficiency of the activities. In a learning and teaching environment which is shaped by an approach that takes into account the individual differences of the target group, efficiency will be able to be accomplished in high levels. Teacher's form of implementation of methods and techniques shaped with strategy developing competence of the teacher, environment facilities, students' attention to the lesson, their competence of using the provided messages, perceptions, etc. is important in earning the language skills.

One must not think that only one methodological approach is enough in foreign language lesson. Apart from the method, substantiality of materials must also be accomplished ${ }^{[2]}$. Enriching the environment with different materials will contribute in catching the attention of students, their motivation in the lesson and fully comprehension of the lesson to be taught.

The teachers of foreign language are composed of either native speakers or teachers who are experienced in that language ${ }^{[5]}$. All teachers who undertake the teaching of Turkish as a foreign language speak Turkish as their mother language. In other words, they are the native speakers of the target language. Whether a native speaker of the target language or an experienced person speaking a different mother language, a teacher who has achieved a fine self-training teaches all features of the target language to its students. According to Peyton, a good foreign language teacher must have the following qualities ${ }^{[3]}$ :

- High level competency in the reading, listening, speaking and writing skills of the target language

- The ability to use the target language for both social and professional purposes in daily life

- The ability to understand the foreign language in both media and press

- An extensive knowledge in art and academic field

- Knowledge of the social, political, historical and economical facts of the area in which the language taught is spoken

- A pedagogical background composed of the individual's development, learning and foreign language acquisition theories

- Knowledge in information technologies and implementation of these technologies in language teaching

The teaching of Turkish in Turkey as a foreign language is performed by either the government (MEB, TIKA) or autonomous organizations with the government's authorization given to these organizations to do so. The first organizations among those that come to our mind are Ankara University TÖMER and Gazi University TÖMER.

Problem: What is the level of the teaching strategies and class activities of the teachers who teach Turkish in Turkey as a foreign language?

\section{Sub problems:}

- Do the teachers who teach Turkish as a foreign language use modern teaching strategies in the learning and teaching process?

- Is the physical environment in which the language teaching activities are performed and the social dimension of the environment (class interaction and the usage of the language) appropriate for the development of the language skills?

- Does the teacher maintain the learning conditions of the students (attention, eagerness, asking questions, speaking, participation in the discussions, taking responsibility) at a sufficient level by enabling them to become active? 
Purpose of the research: The purpose of this research is to determine the competency level of the teachers who teach Turkish in Turkey as a foreign language in the learning and teaching process and to offer the language lecturers their strategies, methods, techniques and class activities which are considered efficient.

Universe and sample: The universe of this research is composed of the teachers who teach Turkish in Turkey as a foreign language. Fifteen samples have been selected among the teachers who work in the institutions which provide the teaching of Turkish as a foreign language in two levels namely secondary education and higher education (state schools: GïH High School \& private course centers: TÖMER 1/2).

Limitedness: The research is limited to 15 teachers, interview form questions among the data collection tools and the extents of observation stated in the observation form.

Method (Collection and analysis of the data): In the research, interview and observation methods have been used in the scope of qualitative approach. 11 questions in the interview form have been asked to 15 teachers who teach Turkish as a foreign language and the answers obtained have been noted down and subjected to content analysis. In the scope of the research, 4 teachers have been observed in the class environment. The findings related to the quality and practices of the teachers who have been observed in 5 extents of observation in the observation form have been noted down. Noteworthy data obtained with interview and observation method have been firstly put into the related sections in the tables. Processed data have been coded with content analysis and it is attempted to obtain some themes. In the last stage of the analysis, the data have been defined and interpreted in accordance with the codes and themes.

Content analysis is to bring together the similar data in the content analysis in the scope of certain concepts and themes and to interpret these data by arranging them in a comprehensible order ${ }^{[18]}$. The understanding of the content of documents is dependent on the determination of the content of words and sentences in the texts with content analysis ${ }^{[17]}$. Coding is an initial and major process for the analysis gravitated towards revealing the content of the data in the qualitative analysis ${ }^{[12]}$.

The findings obtained with personal knowledge, interview and observation forms used as data collection tools have been classified in two categories. The first one is the findings related to personal knowledge and the second one is the findings obtained with the interview and observation forms.
Statistical analysis: Findings related to personal knowledge: Defining analysis related to variables such as the gender, occupational seniority, educational institution of graduation, teaching program, etc. of the teachers has been conducted. Analysis has been performed with the Statistical Package for the Social Sciences version 11.0 (SPSS Inc., Chicago, IL, USA).

\section{Data analysis (The findings obtained with interview and observation forms):}

- In the qualitative approach-based content analysis of the data obtained with interview questions, the following process has been followed: The processing of the data obtained from the answers of the reference people for the questions in the interview form, assigning themes by coding based on noteworthy answers, definition and interpreting in accordance with codes and themes.

In the analysis process of the data obtained with interview,

$\mathrm{R}_{1}, \mathrm{R}_{2}, \mathrm{R}_{3} .$. : Defines the questions of the researcher,

$\mathrm{T}_{1}, \mathrm{~T}_{2}, \mathrm{~T}_{3} \ldots$ : Defines the reference people whose opinions have been taken (Teachers who teach Turkish as a foreign language),

$[1],\left[{ }^{2}\right],[3] \ldots$ : Defines the noteworthy answers (the number of words, sentences and paragraphs)

- The observation data analysis process conducted in order to reveal the teaching strategies and practices presented by the teachers who teach Turkish in Turkey as a foreign language is as follows: The processing of the qualities related to the extents of observation, assigning themes by coding based on noteworthy answers, defining and interpreting in accordance with codes and themes.

In the analysis process of the data obtained with observation,

$E_{1}, E_{2}, E_{3} \ldots$ : Defines the extent of observations taken into account,

$\mathrm{T}_{1}, \mathrm{~T}_{2}, \mathrm{~T}_{3} \ldots$ : Defines the reference people observed (Teachers who teach Turkish as a foreign language),

$\left[{ }^{1}\right],\left[^{2}\right],\left[^{3}\right] \ldots$ : Defines the number words, sentences and paragraphs that determine the noteworthy qualities and practices

\section{Findings:}

Findings related to personal knowledge: $A s$ it is shown in the Table 1 , a total of 15 teachers ( 9 male and5 male) have participated in the research. Female teachers constitute $60 \%$ of the total participants while male teachers constitute $40 \%$ of the total participants. 
Table 1: Distribution of teachers according to their genders

\begin{tabular}{lrr}
\hline Distribution of teachers according to their genders & $\mathrm{f}$ & \multicolumn{1}{c}{$(\%)$} \\
\hline Woman & 9 & 60.00 \\
Man & 6 & 40.00 \\
Total & 15 & 100.00 \\
\hline
\end{tabular}

Table 2: Distribution of teachers according to their seniority status Distribution of teachers according to their

\begin{tabular}{lcc} 
seniority status & $\mathrm{f}$ & $(\%)$ \\
\hline $1-5$ years & 9 & 60.00 \\
6-10 years & 5 & 33.33 \\
11-15 years & 1 & 6.67 \\
16- 20 years & - & - \\
21 years or more & - & - \\
Total & 15 & 100.00 \\
\hline
\end{tabular}

Table 3: Educational institutions of graduation

\begin{tabular}{lrr}
\hline Educational Institutions of Graduation & $\mathrm{f}$ & \multicolumn{1}{c}{$(\%)$} \\
\hline Faculty of Education & 5 & 33.33 \\
Faculty of Arts and Sciences & 8 & 53.34 \\
Faculty of Language, History and Geography & 2 & 13.33 \\
Total & 15 & 100.00 \\
\hline
\end{tabular}

In the Table 2, the distribution of the number of years that the teachers perform the duty of teaching Turkish as a second language is seen. When the distribution of the teachers according to their seniority is examined, a high level of concentration is seen in the 1-5 years of occupational seniority with $60 \%$ and 10 people. The seniority level of the other teachers is as follows respectively: 6-10 years of occupational seniority with $33.3 \%$ ratio and 5 people and $11-15$ years of occupational seniority with $6.67 \%$ ratio and 1 person. It is remarkable that there is no teacher who has 16 years of seniority or more.

When the distribution of the teachers in accordance with their educational institutions of graduation is observed, it is shown in Table 3 that the ratio of 5 people having graduated from the Faculty of Education is $33.33 \%$, the ratio of 2 people having graduated from the Faculty of Language, History and Geography is $13.33 \%$ and the ratio of 8 people having graduated from the Faculty of Arts and Sciences is $53.34 \%$ being the highest ratio among them.

It is shown in Table 4 that only 1 of the teachers who teach Turkish as a foreign language $(6.67 \%)$ is a graduate of the Department of Turkish Language Teaching. Three teachers are graduates of the Department of Turkish Language and Literature Teaching $(20.00 \%), 7$ teachers are graduates of the Department of Turkish Language and Literature $(46.66 \%), 1$ teacher is a graduate of the Department of English/French Language and Literature Teaching $(6.67 \%), 1$ teacher is a graduate of the Department of English/French Language and Literature (6.67\%) and 2 teachers are graduates of Department of Linguistics.
Table 4: Department of graduation/education program

\begin{tabular}{lrr}
\hline Department of Graduation/Education Program & $\mathrm{f}$ & \multicolumn{1}{c}{$(\%)$} \\
\hline Turkish language teaching & 1 & 6.67 \\
Turkish language and literature teaching & 3 & 20.00 \\
Turkish language and literature & 7 & 46.66 \\
English/French language and literature teaching & 1 & 6.67 \\
English/French language and literature & 1 & 6.67 \\
Linguistics & 2 & 13.33 \\
Total & 15 & 100.00 \\
\hline
\end{tabular}

Table 5: Variety of school/course center

\begin{tabular}{lrr}
\hline Variety of School/Course Center & f & \multicolumn{1}{c}{$(\%)$} \\
\hline State School & 6 & 40.00 \\
Private Course Center & 9 & 60.00 \\
Total & 15 & 100.00 \\
\hline
\end{tabular}

Table 6: The factors that affected the teachers in deciding to perform the duty of teaching Turkish as a foreign language

$\mathrm{R}_{1}$ : What are the factors that affected you in deciding to perform the duty of teaching Assigning themes

Turkish as a foreign language? by coding

$\mathrm{T}_{6.10 .13}$ : I took this job by chance. It was not Appointment a conscious choice $\left.{ }^{1}\right]$

$\mathrm{T}_{7}$ : I took this job by appointment $\left[{ }^{2}\right]$

$\mathrm{T}_{9}$ : I want to know how Turkish is taught in basic level $\left[^{3}\right]$

$\mathrm{T}_{12}$ : I voluntarily and deliberately chose the job of teaching Turkish as a foreign language $\left[{ }^{4}\right]$

$\mathrm{T}_{11}$ : My actual purpose was to make career in taking this duty $\left[{ }^{5}\right]$

$\mathrm{T}_{11,14,15}$ : It was a job that I could enjoy doing and presenting Turkish culture and learning about other cultures attracted me $\left[{ }^{6}\right]$

It is shown in Table 5 that among the teachers who participated in the research, $6(40.00 \%)$ work in state schools and $9(60.00 \%)$ work in private course centers.

The findings obtained with interview and observation forms: The qualitative approach based content analysis of the data obtained with interview questions.

Defining and interpreting the data in accordance with the codes and themes (Table 6).

Most of the teachers have stated that they took the job of teaching Turkish as a foreign language by chance, by appointment, they thought that it was a job that they could enjoy, their purpose was to make career and to learn about cultures. Only one teacher has stated that he chose the job of teaching Turkish as a foreign language voluntarily and deliberately. When the graduation departments and teaching programs of the teachers are observed (Table 4), the number of teachers who graduated from the department of Turkish Teaching is 1 . In view of this, it is understood that the teachers did not choose this job as a natural result of their learning process. However, teaching Turkish as a foreign language is a special area of expertise. Teachers who teach Turkish as a second language must be 
trained just like German, French and English teachers. Being a native speaker of Turkish and graduating from the Department of Turkish Language and Literature is not enough to teach Turkish as a foreign language ${ }^{[19]}$.

Defining and interpreting the data in accordance with the codes and themes (Table 7).

In response to the question, Did you get a special education for teaching Turkish as a foreign language? About 5 teachers have stated that they underwent teacher training, 2 teachers have stated that they attended orientation seminars, 1 teacher has stated that he took the lesson of Teaching Turkish to Foreigners. About 6 teachers did not get a special education in this field. It is remarkable that most of the teachers in our study group do not have such competency while it is required for the teachers who will render foreign language teaching which requires a pedagogical background to get at least an undergraduate education.

Defining and interpreting the data in accordance with the codes and themes (Table 8).
One teacher has stated that he gives lessons in a specially designed language laboratory and other teachers have stated that they give lessons in normal classrooms. Giving lessons in specially designed classrooms is important for the motivation of the students and the productivity of the education. The fact that only one teacher gives lessons in a specially designed classroom is a case that has to be considered.

Defining and interpreting the data in accordance with the codes and themes (Table 9).

The text book and the student practice books specially prepared for teaching Turkish as a foreign language are followed. TÖMER 1 Hitit Turkish for Foreigners, TÖMER 2 Turkish for Foreigners and TiKA Sun Turkish book sets are followed. The fact that the text books which are the quintessential materials of learning and teaching process is assessed as an appropriate practice.

Defining and interpreting the data in accordance with the codes and themes (Table 10).

Table 7: The case of getting a special education of teachers for teaching Turkish as a foreign language

$\mathrm{R}_{2}$ : Did you get a special education for teaching Turkish as a foreign language?

Did you attend any course or seminar for that purpose?

$\mathrm{T}_{1,2,3,4,14}$ : Yes, I underwent training in Ankara TÖMER for 6 months. I observed teachers who are specialized

Assigning themes by coding

in this field $\left[{ }^{1}\right]$

$\mathrm{T}_{5,7,8,9,10,11}$ : I did not get a special education $\left[{ }^{2}\right]$

$\mathrm{T}_{12,13}$ : I attended an orientation seminar in my institution when I started my job $\left[^{3}\right]$

$\mathrm{T}_{15}$ : During my undergraduate education, $\mathrm{I}$ took the lessons of teaching Turkish to foreigners and teaching Turkish to the Turks Abroad $\left[{ }^{4}\right]$

Table 8: The environment which was made lessons

$\mathrm{R}_{3}$ : Do you give your lessons in specially designed language classrooms or in normal classrooms?

Training

Orientation

Seminar

Undergraduate education

$\mathrm{T}_{6,8}$ : I give lessons in a specially designed classroom $\left[{ }^{1}\right.$

$\mathrm{T}_{9,10,13,15}$ : I give lessons in a normal classroom $\left[^{2}\right]$

$\mathrm{T}_{11,14}$ : I give lessons in a classroom of 15 students $\left[^{3}\right]$

$\mathrm{T}_{12}$ : I give lessons in a normal classroom. I do not think that giving lessons in language laboratories is beneficial $\left[{ }^{4}\right]$ Specially designed language laboratory

Table 9: The case of following the lesson and student practice books specially prepared for teaching Turkish as a foreign language

$\mathrm{R}_{4}$ : Do you follow the lesson and student practice books specially prepared for teaching Turkish as a foreign language?

$\mathrm{T}_{1,2,3,4}$ : Yes, book set and small dictionary books from Hitit Publications $\left[{ }^{1}\right]$

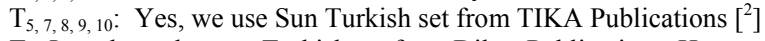

$\mathrm{T}_{6}$ : I used step by step Turkish set from Dilset Publications. However, I think that these

publications are not efficient $\left[^{3}\right]$

$\mathrm{T}_{11,12,13,14}$ : We use Turkish for Foreigners set prepared by TÖMER (2) $\left[{ }^{4}\right]$

Table 10: The density of grammar subjects in the practices

$\mathrm{R}_{5}$ : Do you think that grammar subjects within the program applied by you are so intense that they prevent the development of language skills?

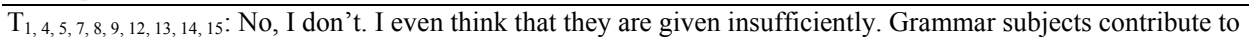
Assigning themes by coding the development of language skills $\left[{ }^{1}\right]$

$\mathrm{T}_{2}$ : I don't think that grammar subjects and reading passages related to those subjects are in required intensity level $\left[^{2}\right]$

$\mathrm{T}_{3,11}$ : Grammar is difficult in some subjects. However, grammar questions are asked in exams like YOS, etc. We focus on language skills apart from grammar $\left[^{3}\right]$

$\mathrm{T}_{6}$ : I think that grammar teaching is important and necessary for a systematical language education. I am aware Specially prepared Turkish book series of the fact that grammar is a tool for developing language skills $\left[{ }^{4}\right]$

$\mathrm{T}_{10}$ : I don't attach great importance to grammar subjects. I try to enable students to comprehend them along awith skills $\left[^{5}\right]$ 
Table 11: To be followed approaches and methods

$\mathrm{R}_{6}$ : Which approaches and methods must be followed in order for students to act more freely and to develop their

language skills? (Searching: invention, interactive, structuring approach, auditory-lingual, auditory-visual,

cognitive, natural, eclectic, etc.

$\mathrm{T}_{2}$ : I try to accomplish group centered learning - teaching environment. I think that the lessons will be more

Assigning themes by coding productive and enjoyable with the student participation $\left[{ }^{1}\right]$

$\mathrm{T}_{3}$ : I give reading and writing activities in coordination. I give activities such as writing poems, completing stories, written and verbal narration, dictation, pronunciation, etc. $\left[^{2}\right]$

$\mathrm{T}_{4,6}$ : I focus on the student-centered education. I give activities that develop their speaking and writing skills apart from the listening that aims to teach students the target language $\left[{ }^{3}\right]$

$\mathrm{T}_{7,10,11}$ : I used mostly interactive learning. I benefit from daily subjects and images. I make practices where students become active $\left[{ }^{4}\right]$

$\mathrm{T}_{8}$ : I prepare an environment for students to associate their mother language with the target language $\left[{ }^{5}\right]$

$\mathrm{T}_{9}$ : I teach grammar subjects as to form language logic $\left[{ }^{6}\right] . \mathrm{T}_{12,13,14}$ : The teacher and the students must form a cozy atmosphere with affection $\left[^{7}\right]$.

Dictation practice

Pronunciation exercises

Interactive learning

Forming an environment for

practical activities

Associating the target

language with the mother language

Table 12: The students' interest levels and skills toward learning Turkish as a foreign language

$\mathrm{R}_{7}$ : What do you think about your students' interest levels and skills toward learning Turkish as a foreign language during the language skill acquisition activities that you provide?

Assigning themes by coding

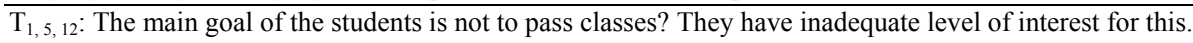

Many students are showing interest in order to pass the class. Only the students who display interest are

able to use Turkish like their native language $\left[^{1}\right]$

$\mathrm{T}_{2,4,6,7,9,10}$ : They have the aim of using Turkish in their daily lives $\left[{ }^{2}\right]$

$\mathrm{T}_{3,13,14}$ : Most of the students have concerns about passing the examinations $\left[{ }^{3}\right]$

$\mathrm{T}_{11,15}$ : Using Turkish in daily life and passing the examination is both a priority $\left[{ }^{4}\right]$

Most of the teachers whose opinions have been taken think positively on the intensity of grammar subjects. One teacher has stated that grammar subjects are intense as in the required level. Two teachers have stated that grammar subjects are difficult. Grammar rules hold great importance in the development of basic language skills. However, the rules of the language must be used functionally in practice (while speaking and writing in daily life). Other than teaching grammar rules and determining whether they know these rules or not, the practices of transforming the knowledge into skill are not conducted adequately. On this matter, Tosun says ${ }^{[16]}$ : Although students have sufficient grammar knowledge, they do not know how to use this knowledge. To help them on how to use this knowledge for communication purposes, new approaches are required which are prepared directly for language learning and teaching. It must be understood that language is not composed only of grammar patterns and word lists. Apart from the view that learning is actualized by acquiring, arranging and keeping the knowledge, teachers must aim to apply the information gained in the studies of language skills acquisition and to provide the permanency by doing $\mathrm{so}^{[14]}$.

Defining and interpreting the data in accordance with the codes and themes (Table 11).

It is understood that teachers do not carry out a systematic strategy, method and technique practice towards the acquisition of basic language skills. As a natural result of the education they receive and in line with their own creativity, every teacher conducts lessons with such methods as dictation, pronunciation exercises, interactive learning by association of the target language with the first language and preparation of environment for practical activities and also attempts to provide the students with language skills. Creating an environment which enables the students who learn Turkish Language as a target language to learn the subjects and words by associating them with their own language is an appropriate practice. In order for the students to be able to learn the new words included in the process, the foreign language teacher might make a target language-mother language matching. Then, permanent learning can be achieved through pronunciation, dictation and such activities. With the help of such works, foreign language teachers are able to benefit from the mother language due to many reasons ${ }^{[15]}$. Mehmedoglu regarding this issue says that thanks to the matching and comparison of the mother language in the education of foreign language, students learn the foreign language not by means of memorization but by deliberate understanding ${ }^{[10]}$. The existence of students who speak different languages requires many methods to be concurrently used. Speaking and writing activities on daily subjects that might attract the attention of the students helps develop the language skills. Focusing on the implementation activities after teaching the form and the function of the subject is a beneficial practice.

Defining and interpreting the data in accordance with the codes and themes (Table 12). 
Table 13: Informing of the students beforehand about issues

$\mathrm{R}_{8}$ : Do you inform your students beforehand about issues such as the acquisitions regarding the lesson and the learning strategies which you follow while you are teaching Turkish as a foreign language?

$\mathrm{T}_{\left.1,4,6,8,10,13: \text { No, I don't [ }{ }^{1}\right]}$

$\mathrm{T}_{2,7,12,15}$ : Yes, I do $\left[^{2}\right]$

$\mathrm{T}_{3,5,9,11,14 \text { : I inform them on special occasions. }\left[{ }^{3}\right]}$

Assigning themes by coding

The significance of

informing about the goals

Table 14: The case of specializing of the teachers in teaching Turkish as a foreign language

$\mathrm{R}_{9}$ : Do you give all of the lessons aimed for the basic language skills (reading, listening, speaking and writing)

in teaching Turkish as a foreign language along with the field of grammar learning or have you specialized

on any of these fields?

$\mathrm{T}_{1,3}$ : I give the lessons related to all skills. However, the teachers of the classes change after the end of

each course stage $\left[{ }^{1}\right]$

$\mathrm{T}_{2,7}$ : I give all lessons related to each skill. However, I believe that it will be beneficial if every teacher specialize on different skills $\left[^{2}\right]$

$\mathrm{T}_{4,5,6,8,9,10,15}$ : I give lessons on all language skills and grammar learning field $\left[^{3}\right]$

$\mathrm{T}_{11,12}$ : Grammar lessons are given by a teacher who is specialized on that field. I give all the lessons

related to other skills $\left[{ }^{4}\right]$

$\mathrm{T}_{13}$ : I only give grammar lessons $\left[{ }^{5}\right]$

Table 15: The importance of the language skills in the practices

$\mathrm{R}_{10}$ : Are you able to attach equal importance to all of the language skills and spare equal time for each of them in the activities?

$\mathrm{T}_{1,7,9}$ : I attach equal importance to all of them, yet I am not able spare equal time for each of them $\left[{ }^{1}\right]$

$T_{2,12,15}$ : I do not attach importance for each skill in the activities $\left[{ }^{2}\right]$

$\mathrm{T}_{3,5,10,11,13}$ : I attach more importance to grammar subjects $\left[{ }^{3}\right]$

$\mathrm{T}_{4}$ : The writing skill is being neglected. The speaking skill stands out. $\left[{ }^{4}\right]$

$\mathrm{T}_{6}$ : I can not say that I spare enough time for the writing and listening skills $\left[^{5}\right]$

According to teachers, some of the students aim to learn Turkish as a foreign language and use it in their daily lives. However, same amount of students have the aim of being successful in the exams and passing their classes. Again according to teachers, very few students display stressful behaviors such as worrying about passing the exams and fear of failing. The main goal of the students must be to learn Turkish as a foreign language and use it in social life rather than to pass the exam. Students will be able to acquire this understanding only if teachers provide them with intellectual horizon. In addition to this, many variables such as the environment in which the education is acquired, the homeland of the students, the family structure and the expectations are significant on this issue.

Defining and interpreting the data in accordance with the codes and themes (Table 13).

As shown in Table 13, 6 teachers stated that they have not informed their students about the works to be done, 4 teachers stated that they have informed their students, whereas 5 teachers stated that they have informed their students on special occasions.

Defining and interpreting the data in accordance with the codes and themes (Table 14).

As it can be shown in Table 14, specialization of teachers in a single language skill is out of question. It is seen that teachers have not specialized in certain fields and only 1 teacher has given grammar lessons. All of the lessons for the field of reading, listening, speaking and writing language skills and the grammar learning are given only by one teacher. Normally, each teacher must specialize in a single language skill and become beneficial to their students by giving lessons for that field.

Defining and interpreting the data in accordance with the codes and themes (Table 15).

More than half of the teachers say that they are not able to spare enough time for each skill in the activities aimed at developing the language skills and that they spare more time for grammar subjects and neglect the writing and listening skills. The activities for the acquisition of language skills are the works that should be carried out in coordination and without prioritizing one over another. In order to enable the students to comprehend the grammar rules in the beginning of the learning and teaching process, a little more time can be spared to grammar rules by emphasizing them. However, in the process of time, equal importance should be attached to understanding and explaining skills and to the field of grammar.

Defining and interpreting the data in accordance with the codes and themes (Table 16).

It is understood that the teachers give homework assignments and hold written and test exams while determining students' acquisition levels of language skills. No matter which measurement means are used 
by the teachers, the most important thing they look for is the students' levels of recalling knowledge. As it can be seen in Table 10, almost all of the teachers attach great importance to knowledge of grammar rules related to the cognitive field. The important thing is not to have knowledge, but to earn an active language user quality by using the acquired knowledge. In addition to teaching their students the ways to have access to knowledge, teachers should also functionalize such mental processes as interpreting the acquired knowledge, forming cause and effect relation, making analysis and evaluation. This functionality manifests itself in the form implementing and turning into behaviors such language skills as understanding the mental proficiencies, speaking and writing. Although the acquisition gained by means of this practice does not seem to be directly useful in such exams as YÖS, it is going to be beneficial in terms of communication and the social life of the person.

The observation data analysis conducted in order to reveal the education strategies and the class practices of the teachers who teach Turkish as a foreign language

Defining and interpreting the data in accordance with the codes and themes (Table 17).

Table 16: The measurement and evaluation activities

$\mathrm{R}_{11}$ : What are the measurement and evaluation activities that you conduct in order to determine the students' acquisition and development levels of language skills?

$\mathrm{T}_{1}$ : We give interim exams. We form grades by means of observation. We have compensatory lessons in order to eliminate the deficiencies determined with the interim exams $\left.{ }^{1}\right]$

$\mathrm{T}_{2,11}$ : After each basic, intermediate and upper level course stage, we give oral exams in order to measure the speaking skills of the students and we give written exams in order to measure their skills of grammar usage, dictation study, composition writing and skills of understanding what is read and written $\left[{ }^{2}\right]$

$\mathrm{T}_{3,4,14}$ : During subject explanation, we evaluate their performance towards the dictation activities with exercises for reading, listening, speaking and writing skills $\left[{ }^{3}\right]$

$\mathrm{T}_{6}$ : I make observations. I give written exams in order to measure the understanding and description skills of students. I make assessments by checking their answers to the questions related to the text I read and by viewing their performances in dictation activities $\left[{ }^{4}\right]$

$\mathrm{T}_{7,12}$ : I give written examination and homework assignments and carry out activities of verbal testing $\left[{ }^{5}\right]$ $\mathrm{T}_{10}$ : I give tests related to the subjects that I explained $\left[{ }^{6}\right]$

$\mathrm{T}_{13,15}$ : In each course stage (basic, intermediate and upper) we give two mid-term exams and one final exam. Final examination is the multiple choice test and the others are written exams $\left[{ }^{7}\right]$

Assigning themes by coding

Post-course stage determination of student success

Oral, homework and written exam

Observation questions related to the text

Multiple choice test and the others are written exams

Table 17: Findings on the qualities and the practices of the teachers that are observed

$\mathrm{T}_{1,2,3,4}$ : School: GiH High School Date: 17-19/12 / 2007 Lesson: Turkish Class: 1st grade of High School

$\mathrm{E}_{1}$ : Physical environment: $\mathrm{T}_{1,2,3,4}$ : The wall color, heating and lighting of the class is really good, there is no sound and noise $\left[{ }^{1}\right] . T_{2,3}$ : The class has a normal desk alignment, and technical sub-structure for the use of material is inadequate $\mathrm{T}_{1,4}$ : The class has a $\mathrm{U}$-shaped desk alignment. Computers, data show and such materials are used $\left[^{2}\right] . T_{1,4}$ : The walls are designed with pictures, plates, student works and such materials $\left[^{3}\right]$ $\mathrm{E}_{2}$ : The social extent of the environment and the interaction: $\mathrm{T}_{1,2,3,4}$ : The way the teacher enters the classroom, his/her way of calling the students, motivating the students and use of his/her body language is at a sufficient level $\left[{ }^{1}\right] . T_{1,2,3,4}$ : In order for the students to actively participate in the lesson, a democratic environment is being created $\left[{ }^{2}\right]$. $T_{?}$ : The students ask questions and speak about the problems of the country and the world $\left[{ }^{3}\right] . \mathrm{T}_{1,2,3,4}$ : The teachers and the students communicate with verbal and non-verbal behaviors and express their feelings and emotions $\left[{ }^{4}\right]$

$E_{3}$ : Classroom activities and the use of language: $T_{1,2,3,4}$ : The works of language skill acquisition are carried out by means of the text $\left.{ }^{1}\right] . T_{1,2,3,4}$ : The teacher spares enough time during the lesson for the reading, listening, speaking and writing activities $\left[{ }^{2}\right]$. $\mathrm{T}_{1,2,3,4}$ : Practical activities related to new words, word groups, sayings, proverbs, etc. in the text are performed in order to improve the vocabulary of the students $\left[{ }^{3}\right] . T_{2,4}$ : Students' acquisition levels related to the activities performed are measured $\left[{ }^{4}\right] . \mathrm{T}_{1,4}$ : Students are asked questions, and the course of the lesson is directed in accordance with their answers $\left[^{5}\right]$.

$E_{4}$ : Evaluation and taxonomic structure: $T_{1,2,3,4}$ : The questions related to the discussed subjects are generally on the cognitive field, however there are not many questions regarding the affective and psychomotor field [ $\left.{ }^{1}\right]$. $\mathrm{T}_{1}$ : In the learning and teaching process, the teacher asks questions. The questions of the teachers are understood the first time $\left[{ }^{2}\right] . T_{1,2,3,4}$ : The questions directed to the students are asked candidly in a conversation mood. $\left[^{3}\right]$. $\mathrm{T}_{1}$ : The questions are directed to all the students in the classroom. Averagely, 20-40 seconds are given to receive an answer to the questions $\left[{ }^{4}\right]$

$E_{5}$ : Learner qualities: $T_{1,2,3,4}$ : Students ask questions during the process of learning and teaching $\left[{ }^{1}\right]$.

$\mathrm{T}_{1,2,3,4}$ : The students are capable of describing their feelings, thoughts and notions properly $\left[^{2}\right] . \mathrm{T}_{3}$ : Students create a discussion environment by asking questions and participate in these discussions $\left[{ }^{3}\right] . T_{1,2,4}$ : Through the course of the lesson, the students attend activities of reading, listening, speaking, writing, asking questions and answering questions etc. $\left[{ }^{4}\right] . T_{1,2}$ : The students are eager to participate in the social activities $\left[{ }^{5}\right]$. $T_{3}$ : Students speak to their friends about the book which they read beside the text book $\left[{ }^{6}\right] . T_{1,2,3}$ : Students generally act in the environment with a consciousness of role and responsibility $\left[^{7}\right]$

Assigning themes by coding

Motivation

Technical equipment

Design of class

Behavior of the teacher

Democratic class

environment

Non-verbal

behaviors and

communication

Teaching activities through texts Improving the vocabulary

Literary products Measuring the level of skill acquisition

Cognitive field Way of asking questions and understandability Target group to whom the questions are directed

Active student

Non-class

social activities 
Physical environment: It has been seen that in terms of technical equipment the walls were enriched with pictures, plates, world map, condition of noun suffixes table and the student work papers formed during the activities. This situation is important in motivating the students and providing them with the targeted language skills. There are no demotivating sounds and noises during the lessons.

The social dimension of the environment and interaction: It is aimed to create a democratic environment in the classrooms. It has been observed that in the class environment the students are generally encouraged when they attempt to ask questions, share their feelings and thoughts on country and world problems and display non-verbal behaviors.

Classroom activities and the use of language: During the lessons, associations are made with daily life and other languages $\left(\mathrm{T}_{2}\right)$. Especially during the activities of vocabulary improvement, teaching the word in the target language by relating it with its equivalent in the mother language enables a permanent learning. The participation of all the students in the lesson and their tendency to use the target language has been clearly observed.

Evaluation and taxonomic structure: During the lesson, exercises are done and questions and answers are exchanged in order to focus the students' attention and to ensure the permanency of the subjects that are taught. It has been observed that the question predominantly focused around the knowledge rather than personal feeling and thought. After a question is given, by means of providing clues and repeating the questions in different ways, the students are ensured to understand the question and are encouraged to give answers.

Learner qualities: This quality can be conceived by examining the activity types of the students, the supervision levels of the learners on learning, the interaction level between the learners and whether the students undertake such roles as implementing, practicing and problem solving ${ }^{[13]}$. It has been observed that the students were eager to learn the target language. Asking questions to the teacher in the class environment, participating in the opened discussions and eagerness for social activities, their efforts to properly describe their feelings, thoughts and opinions, their desire to read a book beside the text book reveals that they have active student qualities. Although their teachers say that students' interest toward Turkish is within the framework of being successful in the exam, their skills and desire to learn language are observed in every activity. Therefore, the teachers can reveal the best studying and learning method of their students. Once the students are ensured to comprehend these qualities, they can be successful by means of planning, organizing and evaluating their learning while studying individually ${ }^{[9]}$. Their eagerness to read a short story book which is in accordance with the level observed in the students must be absolutely responded. Specially compiled texts should be prepared for the students who learn Turkish as a foreign language and studies should be conducted related to these texts. In addition to this, in time literary texts should be used with the aim of developing the skill of reading.

\section{RESULTS}

Teachers began their jobs of teaching Turkish as a foreign language as a result of assignment, the idea of making a career, the intention of getting to know the cultures or coincidentally and did not receive a particular training for this job. Foreign language education is generally given in normal classes, yet only 1 teacher deliver courses in a specially designed language laboratory.

In Turkish language education as a foreign language, specially prepared text books and student work books are followed.

Majority of the teachers think that grammar subjects should be predominant.

Teachers do not apply a systematic strategy, method or technique in teaching a foreign language and they give lessons with traditional methods.

Some of the students aim to use Turkish as a foreign language in social life, whereas the others aim to be successful in the exams and pass their lessons.

Half of the teachers inform the students about the targets and the works that are to be carried out.

It is seen that expert teachers do not participate in each of the language skills and that few teachers deliver lessons as an expert in a skill or learning field. Since this is the case, the teachers are apparently not able to attach equal importance and spare adequate time to each skill.

The teachers measure the students' acquisition level of language skill with oral tests, performance homework assignments, written exams and tests. Regardless of their measurement means, the first thing that the teachers look for is students' recalling degree of the information taught (cognitive proficiency).

When such variables as the classroom activities, the use of language and the interaction are viewed, 
generally a social environment is established with a democratic understanding. When the qualities of the learners are viewed, the active participation of students in the lessons also affirms this fact.

\section{DISCUSSION}

With this study, it has been seen that the teachers who teach foreign language generally do not have the necessary training to perform this duty and that they do not deliver lessons in a technically well-equipped language laboratories. It has been observed that traditional methods were preferred instead of modern strategies and methods. In addition to this, the efforts of teachers in using social-emotional teaching methods by means of making associations between the target language and the mother language have not been overlooked. In this respect, it has been seen that dictation activities, pronunciation exercises and such activities as speaking and writing about daily subjects that might interest the students have been carried out. The first thing that should be done in foreign language education is to make the target group conscious of the advantages of learning a foreign language. Rather than acting with the aim of passing an exam, students should act with the awareness that the foreign language they are to learn will strengthen their communication power and enrich their social lives and with this point of view they should set a target of learning a foreign language for themselves. Students will acquire this understanding only if the teachers provide them with the intellectual horizon.

Contrary to modern countries, it has been seen that a single teacher delivered the reading, listening, speaking and writing skills and all the lessons related field of grammar learning. Every teacher must deliver courses on his/her specialized field of skills and inform the students beforehand about the method to be followed, material to be used and the acquisitions aimed to be achieved.

\section{CONCLUSION}

At the end of the studies, in addition to measuring the students' levels of knowledge recalling, the functionality of such mental processes as interpreting the acquired knowledge, forming cause and effect relation and making an analysis and evaluation should be tested.

In order for the students to better learn the target language, they must be ensured to acquire such habits as attending actively in the classroom, participating in social activities outside the classroom and reading a book in addition to the text book, etc.

Importance should be attached to the training of qualified foreign language teachers in order for the foreign language education to be implemented in accordance with the international norms.

To ensure that the importance of foreign language education is understood, it must be discussed in academic environments and the conduct of studies must be prioritized which search and examine subjects on foreign language education.

\section{REFERENCES}

1. Antony, E., 1963. Approaches methods and technique. English Language Teaching J., 17: 63-67.

2. Arak, H., 2006. The role of english and comparative grammar in learning german as a second foreign language, Erciyes University. J. Soc. Sci. Inst. Kayseri, 21: 205-216. http://sbe.erciyes.edu.tr/dergi/sayi_21/12-(205-216. $\% 20$ syf.).pdf.

3. Aydogan, I. and Z. Cilsal, 2007. Education process of foreign language teachers (Turkey and other countries). J. Soc. Sci. Institute. Kayseri: 22: 179-197. http://sbe.erciyes.edu.tr/dergi/ sayi_22/11-\%20(179-197.\%20syf.).pdf.

4. Chamot, A.U. and L. Kupper, 1989. Learning strategies in foreign language instruction. Foreign Language Ann., 22: 13-24. http://eric.ed.gov/ERICWebPortal/custom/portlets/ recordDetails/detailmini.jsp?_nfpb=true\&_\&ERIC ExtSearch_SearchValue_0=-EJ385531\&ERICExtS earch_SearchType_0=no\&accno=EJ385531.

5. Day, R., 1993. Models and the knowledge base of second language teacher education. Sec. Language Stud., 11: 1-13. http://eric.ed.gov/ERICWebPortal/custom/portlets/ recordDetails/detailmini.jsp?_nfpb=true\&_\&ERIC ExtSearch_SearchValue_0=ED370359\&ERICExtS earch_SearchType_0=no\&accno=ED370359.

6. Demircan, O., 19900. Foreign Language Teaching Methods Approaches and Methods in Foreign Language Teaching. Can Offset, Istanbul.

7. Demirel, O., 1993. Foreign Language Teaching, Principles-Methods-Technique. 3rd Edn., Usem Publication, Ankara.

8. Gattegno, C., 1972. Teaching foreign languages for english in schools: The silent way. TESOL Q., 8: 305-314. http://www.jstor.org/pss/3586174.

9. Hansen, I.F., 2006. How to become a successful language learner anatomy, styles and strategies revisited. Language J., 133: 29-59. 
10. Mehmedoglu, A., 2000. On The comparative training of mother tongue with foreign language teaching, Ataturk University Journal of Kazim Karabekir Education Faculty, Linguistic and Language Teaching (Special Issue). Erzurum: 4: 153-165.

11. Oxford, R.L., 1990. Language Learning Strategies: What Every Teacher Should Know. 1st Edn., Heinle ELT., Boston, ISBN: 10: 0838428622, pp: 368.

12. Punch, K.F., 2005. Introduction to Social Research: Quantitative and Qualitative Approaches. Sage Publication Ltd., Ankara, ISBN: 10: 0761944176 pp: 336.

13. Richards, J.C. and T.S. Rodgers, 1986. Approaches and Methods in Language Teaching. 1st Edn., Cambridge University Press, new York, ISBN: 10: 0521312558, pp: 192.

14. Sezer, A., 1988. The Situation of ProductiveReflexive Grammar in Foreign Language Teaching. Hacettepe Univ. J. Educ. Fac., 3: 141-151. http://193.140.216.63/ 19883ayhan\%20sezer.pdf.
15. Tercanlioglu, L., 2000. Using Turkish in the EFL classroom Ataturk University Journal of Kazim Karabekir Education Faculty, Linguistic and Language Teaching (Special Issue) Erzurum: 4: 327-334.

16. Tosun, C., 2006. A new view to the old and new methods in foreign language teaching and learning. J. Arts Sci., 5: 79-88. http://jas.cankaya. edu.tr/jas5/09-cengiz.pdf.

17. Yaman, H. and Y. Erdogan, 2007. The effect of internet on Turkish language: A qualitative study. J. Language Linguist. Stud., 3. http://www.jlls.org/Issues/Volume\%203/No.2/hya man_yerdogan.pdf.

18. Bryce, L.B., 2003. Qualitative Research Methods in Social Sciences. 5th Edn., Seckin Publications, Allyn and Bacon, Ankara, ISBN-10: 0205379052, pp: 352. 